\title{
Pengaruh Diameter Batang Bawah dan Hormon BAP (Benzyl Amino Purin) Terhadap Keberhasilan Sambung Pucuk Sawo
}

\section{Effect of Diameter Lower Stem and BAP (Benzyl Amino Purin) Hormone on the Success of Top Grafting Sapodilla}

\author{
Nabila Nuraini Fatikhasari*, Karno, Budi Adi Kristanto \\ Department of Agroecotechnology, Faculty of Animal and Agricultural Science, Diponegoro University, Semarang, Indonesia. \\ ${ }^{*}$ Corresponding author. nabilanurainifpp@gmail.com
}

Received: October 5, 2020; Accepted: November 26, 2020; Published: April 1, 2021

\begin{abstract}
Sawo is a tropical native fruit from Indonesia, demand fot the fruit of sawo is increasing every year, one of the most effective ways to consumer demand is to vegetatif propagation that is top grafting. Top grafting can be accelerated by the addition of plant growth regulators. The purpose of this research was to know the success of top grafting of sawo plants at various sizes of diameter plant seedling and levels of BAP concentration. The method used was factorial complete randomized design with 2 factor,the first factor was diameter plant seedling (small, medium and big) and the second factor was concentrations of $\operatorname{BAP}(0,100$ and $200 \mathrm{ppm})$ with 5 replications. The result showed that diameter plant seedling small and medium gave a significant effect $(P<0.05)$ on time of shoot, number of leaf and long of shoot. The levels of BAP concentration 100 and 200 ppm gave a significant effect on the time of shoot, number of shoot and long of shoot and percentage of success. There is interaction of diameter seedling and concentration of BAP against top grafting of sawo varieties jumbo vietnam.
\end{abstract}

Key words: plant growth; sitokinin; vegetative

Cite this as: Fatikhasari, N. N., Karno \& Kristanto, B. A. (2021). Pengaruh diameter batang bawah dan hormon BAP (Benzyl Amino Purin) terhadap keberhasilan sambung pucuk sawo. Agrosains : Jurnal Penelitian Agronomi, 23(1), 12-18. DOI: http://dx.doi.org/10.20961/agsjpa.v23i1.44696

\section{PENDAHULUAN}

Sawo merupakan salah satu buah tropis yang banyak ditanam di Indonesia. Buah sawo juga relatif digemari warga Indonesia lantaran memiliki rasa manis, daging buah yang tebal dan tidak berserat serta biji yang gampang dilepas dari daging buah. Produktivitas buah sawo di Indonesia menurut tahun 2016-2019 mengalami kenaikan, tahun 2016 sebanyak 132.284 ton/tahun dan tahun 2017 sebanyak 133.609 ton/tahun, sedangkan tahun 2019 produktivitas sawo meningkat hingga 144.966 ton/tahun (BPS, 2019). Pada tahun 2016 provinsi Jawa Barat merupakan provinsi sebagai penghasil buah sawo terbesar di Indonesia dengan output produksi sebesar 22.308 ton/tahun (BPS, 2018). Di Indonesia masih banyak kultivar sawo yang komersial dan banyak diusahakan oleh petani yaitu sawo Sukatali (Sumedang, Jawa Barat).

Sawo memiliki rasa buah yang manis dan berbentuk bulat. Buah sawo mempunyai bentuk yang relatif bervariasi mulai dari bulat, oval sampai lonjong dan memiliki kulit buah berwarna cokelat, daging buah yang cukup tebal, bertekstur dan menghasilkan rasa manis (Woo et al., 2013). Selain dikonsumsi sebagai buah sawo dapat digunakan sebagai obat alternatif batuk dan demam serta membantu mencegah obesitas, diabetes dan displidemia (Barbalho et al., 2015). Sawo memiliki batang besar, berwarna abu kehitaman sampai coklat tua. Seluruh batang sawo mengandung getah berwarna putih susu kental dan lengket. Sawo memiliki daun tunggal yang menumpuk pada ujung ranting, berbentuk bundar telur, berwarna hijau tua mengkilap, dan memiliki sedikit bulu (Sudrajat, 2010). Sawo dapat dibudidayakan pada dataran tinggi hingga rendah. Sawo adalah salah satu buah tropik dataran tinggi, namun terdapat varietas yang dapat tumbuh baik di dataran rendah ( $\mathrm{Li}$ et al., 2019). Sawo adalah tanaman yang mudah menyesuaikan diri terhadap suhu, tetapi kondisi suhu yang terlalu tinggi dapat menghambat pertumbuhan sawo. Sawo cocok ditanam pada ketinggian hingga 1200 mdpl dan curah hujan $2.000-3.000 \mathrm{~mm} /$ tahun dan suhu $22-32^{\circ} \mathrm{C}$ (Setyowati, 2008). Sawo diusahakan ditanam pada lahan yang terkena sinar matahari secara penuh untuk mendapatkan pertumbuhan dan hasil produksi yang terbaik (Schaffer et al., 2013). Sawo dapat dikembangbiakkan baik secara generatif maupun vegetatif. Secara umum, sawo dikembangbiakkan dengan cara sambung pucuk. Perbanyakan secara vegetatif merupakan cara untuk mendapatkan bibit kualitas tinggi dan waktu panen yang lebih cepat (Yanti et al., 2013).

Prinsip melakukan teknik sambung adalah kecocokan antara entres dengan batang bawah. Ukuran batang bawah mempengaruhi diameter entres yang akan digunakan. Batang bawah dengan ukuran besar $(0,55-0,60 \mathrm{~cm})$ menghasilkan tunas entres dengan diameter yang lebih besar dan berbeda nyata 
dibandingkan dengan ukuran batang bawah yang lebih kecil (Sudjijo, 2009). Sambung pucuk yang berhasil akan terlihat dari cirinya yaitu muncul tunas baru. Ciri-ciri keberhasilan sambung pucuk adalah munculnya tunas baru dalam waktu kurang lebih 4 minggu setelah dilakukannya sambung pucuk (Sukendro et al., 2010). Sambung pucuk tidak mengubah susunan genetis tanaman. Sambung pucuk atau grafting bertujuan untuk memperoleh hasil yang unggul sama seperti induknya, cepat menghasilkan buah dan dapat memperbaiki jaringan yang rusak (MIR \& Kumar, 2011). Faktor keberhasilan sambung pucuk dipengaruhi oleh beberapa hal. Keberhasilan sambungan dan jumlah daun yang dihasilkan dipengaruhi oleh pemilihan batang bawah, seperti kondisi kesehatan batang bawah dan umur batang bawah (Izadi et al., 2014). Batang bawah juga mempengaruhi keberhasilan sambungan. Perbandingan diameter entres dan batang bawah merupakan faktor utama keberhasilan sambungan pada tanman kakao (Sari \& Susilo, 2012). Batang bawah merupakan salah satu faktor keberhasilan pertautan tanaman. Keberhasilan teknik okulasi dipengaruhi oleh diameter dan umur batang bawah tanaman karet (Widiatmoko \& Ashari, 2018). Ukuran diameter batang bawah menunjukkan umur batang bawah yang berpengaruh terhadap keberhasilan pertautan sambungan. Batang bawah yang terlalu tua maupun muda akan menjadi faktor keberhasilan sambungan ( $\mathrm{Li}$ et al., 2019).

Hormon sitokinin adalah salah satu hormon pertumbuhan yang terdapat pada semua jenis tanaman. Sitokinin berperan pada pembelahan sel dan mendorong terbentuknya tunas baru pada tanaman. BAP (Benzil Amino Purin) merupakan salah satu hormon sitokinin buatan. Pembelahan, pertumbuhan dan perkembangan sel tanaman dapat ditingkatkan dengan pemberian hormon sitokinin (Schaller et al., 2015). Waktu muncul tunas akan dipercepat dengan penambahan sitokinin. Waktu muncul tunas dapat ditingkatkan dengan pemberian sitokinin karena berpengaruh dalam pembelahan sel dan inisiasi pucuk (Russo et al., 2020). Pemberian hormon tumbuh tanaman akan meningkatkan pertumbuhan tanaman. Jumlah tunas, dan tingkat keberhasilan hidup tanaman Adenium meningkat meningkat hingga $50 \%$ dengan pemberian hormon BAP 100 ppm (Rochmatino \& Prayoga, 2011). BAP membantu pertumbuhan tunas baru tanaman. Konsentrasi BAP 100-200 ppm mempengaruhi peningkatan jumlah tunas baru rata-rata 5 tunas pada tanaman Mattiola incana (Maiti \& Bidinger, 2018). Penambahan hormon BAP akan meningkatkan pertumbuhan tunas dan cabang tanaman. Tunas baru, cabang dan daun tanaman karet dapat dirangsang dengan pemberian BAP 250 ppm hingga 8 tunas baru (Pratomo et al., 2010). Zat pengatur tumbuh seperti auksin dan sitokinin membantu meningkatkan pertumbuhan pada teknik sambung. Panjang tunas baru dapat meningkat dipengaruhi oleh pemberian hormon auksin dan sitokinin pada entres tanaman kakao menggunakan teknik sambung pucuk (Ahanger et al., 2020). Pemberian hormon BAP yang ditingkatkan diharapkan akan meningkatkan keberhasilan hidup dan mempercepat waktu keberhasilan sambung pucuk pada sawo. Perbanyakan tanaman sawo di Indonesia memiliki banyak masalah pada pertumbuhan awal sehingga rentan mngalami kegagalan. Faktor yang mempengaruhi keberhasilan sambung pucuk antara lain ukuran diameter batang bawah. Berdasarkan penelitian sebelumnya menyatakan bahwa penggunaan batang bawah durian varietas DCK-01 dengan ukuran diameter batang bawah besar $(0,55-0,60 \mathrm{~cm})$ dengan entres varietas Hepe mampu menghasilkan pertumbuhan terbaik pada sambung pucuk (Sudjijo, 2009). Penambahan zat pengatur tumbuh pada teknik sambung pucuk juga memperkecil kegagalan yang terjadi. Pemberian BAP 200 ppm memberikan persentase hidup hasil teknik sambung cukup tinggi dan rata-rata jumlah tunas meningkat hingga $50 \%$ lebih banyak daripada pemberian NAA 200 ppm (Rochmatino \& Prayoga, 2011). Kegagalan sambung pucuk tanaman sawo akan menyebabkan rendahnya hasil produksi. Penentuan ukuran diameter batang bawah yang tepat dan pemberian hormon BAP diharapkan mampu meningkatkan persentase keberhasilan dan pertumbuhan sambung pucuk tanaman sawo. Penelitian ini bertujuan untuk mengkaji keberhasilan sambung pucuk sawo pada berbagai ukuran diameter batang bawah dan konsentrasi BAP, serta untuk mengetahui interaksi antara berbagai ukuran diameter batang bawah dan konsentrasi BAP terhadap pertumbuhan awal sambung pucuk sawo.

\section{BAHAN DAN METODE}

Penelitian dilaksanakan pada bulan Desember 2019 - Februari 2020 di Lokasi Kebun Perbanyakan CV Putra Tani, Kota Semarang dan Griya Kendal Asri, Kota Kendal serta Laboratorium Fisiologi dan Pemuliaan Tanaman, Fakultas Peternakan dan Pertanian, Universitas Diponegoro Semarang pada ketinggian $180 \mathrm{mdpl}$.

Bahan yang digunakan dalam penelitian ini adalah batang bawah sawo dengan varian sawo kecik diameter yang berbeda, entres yang berasal dari tunas air pohon sawo dengan varietas Vietnam jumbo, bubuk BAP, dan $\mathrm{HCl} 1 \mathrm{~N}$. Alat yang digunakan dalam penelitian adalah erlenmeyer untuk menyimpan larutan hormon BAP gunting dahan untuk mengambil entres yang akan digunakan, pisau okulasi untuk menyayat batang plastik okulasi untuk mengikat sambungan, plastik label untuk menyungkup san menandai sambungan.

Penelitian ini dilaksanakan menggunakan rancangan acak lengkap (RAL) pola faktorial $3 \times 3$ dengan 5 kali ulangan. Faktor pertama adalah ukuran diameter batang bawah dengan 3 taraf perlakuan yaitu $A 1: 0,45-0,55 \mathrm{~cm}$ (kecil), A2 : 0,56-0,65 cm (sedang) dan A3 : 0,66-0,75 (besar). Faktor kedua adalah konsentrasi BAP dengan taraf 3 perlakuan yaitu S1 : 0 ppm, S2: 100 ppm, dan S3 : 200 ppm. Kombinasi perlakuan sebanyak 9 perlakuan dan 5 kali ulangan, sehingga terdapat 90 unit percobaan yang setiap unit percobaan terdiri dari 1 sawo.

Pelaksanaan sambung pucuk dilakukan dengan cara batang bawah dipotong membentuk huruf " $V$ " dengan panjang $3 \mathrm{~cm}$ sesuai ukuran diameter yang ditentukan. Entres dipotong 5-7 cm, sebelum entres disambungkan dengan batang bawah, entres dicelupkan hormon BAP sesuai perlakuan. Entres dan batang bawah ditautkan dan diikat plastik/grafting tape dari bawah ke atas hingga tidak ada celah. Sambungan yang telah diikat diberi sungkup. Pemeliharaan dari penyiraman yang dilakukan secara rutin pagi hari dengan takaran yang sama setiap 
polybag. Penyiangan dilakukan dilakukan ketika terdapat gulma yang tumbuh dengan membersihkan atau mencabut gulma yang mengganggu. Parameter yang diamati adalah:

1. Waktu muncul tunas: Waktu muncul tunas diamati setiap hari hingga semua hasil sambung tanaman muncul tunas sampai pengamatan terakhir minggu ke 9.

2. Jumlah tunas: Jumlah tunas dihitung pada minggu ke 9.

3. Panjang tunas: Panjang tunas diukur pada minggu ke 9.

4. Jumlah daun: Jumlah daun dihitung pada tiap minggu pengamatan hingga minggu ke-9.

5. Persentase keberhasilan (\%): Persentase keberhasilan dihitung berdasarkan jumlah tanaman sambung pucuk yang hidup sampai akhir pengamatan. Sambungan yang hidup ditandai dengan adanya daun yang hijau atau tidak ada daun sama sekali namun batang dalam kondisi segar. Tanaman yang mati ditandai dengan batang dan daun berwarna cokelat, diamati 1 bulan setelah penyambungan dengan rumus:

Persentase sambungan hidup $=\frac{\text { Sambungan hidup }}{\text { Jumlah sambungan }} \times 100$

Data yang diperoleh diolah menggunakan Analisis Varians (ANOVA) yang untuk menguji keragaman data dan pengaruh perlakuan menggunakan uji $\mathrm{F}$, dan apabila terdapat pengaruh nyata, maka dapat dilanjutkan dengan Duncan's Multiple Range Test (DMRT) dengan taraf 5\%.

\section{HASIL DAN PEMBAHASAN Waktu Muncul Tunas}

Hasil analisis ragam menunjukkan bahwa tidak terdapat interaksi antara diameter batang bawah dan konsentrasu BAP terhadap waktu muncul tunas tanaman sawo. Perlakuan diameter batang bawah berpengaruh terhadap waktu muncul tunas tanaman sawo, berdasarkan hasil uji lanjut DMRT $(P<0,05)$ disajikan pada Tabel 1. Perlakuan konsentrasi BAP berpengaruh terhadap waktu muncul tunas, berdasarkan hasil uji lanjut DMRT $(P<0,05)$ disajikan pada Tabel 1.

Tabel 1. Waktu Muncul Tunas

\begin{tabular}{ccccc}
\hline Diameter & \multicolumn{3}{c}{ Konsentrasi BAP $(\mathrm{ppm})$} & \\
\cline { 2 - 4 } Batang & 0 & 100 & 200 & Rata-rata \\
Bawah & & & & \\
\hline Kecil & 24,20 & 17,60 & 9,20 & $17,00 \mathrm{~b}$ \\
Sedang & 18,60 & 14,00 & 11,60 & $14,73 \mathrm{~b}$ \\
Besar & 31,60 & 27,20 & 24,00 & $27,60 \mathrm{a}$ \\
\hline Rata-rata & $24,80 \mathrm{a}$ & $19,60 \mathrm{~b}$ & $14,93 \mathrm{c}$ & \\
\hline
\end{tabular}

Keterangan: Superskrip yang berbeda pada kolom atau baris rata-rata yang sama menunjukkan perbedaan nyata $(P<0,05)$. Superskrip yang berbeda pada matriks interaksi menunjukkan perbedaan nyata $(P<0,05)$.

Berdasarkan Tabel 1. dapat diketahui bahwa ukuran diameter batang bawah sedang memberikan hasil signifikan dengan rata-rata waktu muncul tunas 14,73 hari dibandingkan dengan ukuran diameter kecil dan besar dengan rata-rata waktu muncul tunas 17 hari dan 27,60 hari. Sambungan yang menggunakan ukuran diameter batang bawah sedang memiliki waktu muncul tunas paling cepat karena umur batang bawah yang digunakan sesuai untuk sambung pucuk dan proses pembelahan sel masih terjadi cukup tinggi sehingga penempelan jaringan, transformasi hara dan air berjalan dengan optimal. Sedangkan diameter batang bawah kecil masih terlalu muda sehingga proses pertautan sebaiknya dibantu dengan penambahan hormon, dapat dilihat pada konsentrasi BAP 0 ppm batang bawah kecil dan sedang memiliki selisih waktu yang cukup besar. Hal ini sesuai dengan pendapat Schaller et al., (2015) yang menyatakan bahwa hormon sitokinin dapat meningkatkan perkembangan sel tanaman, sitokinin dapat meningkatkan pembelahan, pertumbuhan dan perkembangan kultur sel tanaman. Ukuran diameter batang bawah yang berbeda menunjukkan jumlah kambium yang dihasilkan oleh batang bawah. Hal ini sesuai dengan pendapat Bucci et al., (2020) menyatakan bahwa keberhasilan teknik okulasi dipengaruhi oleh diameter dan umur batang bawah tanaman karet karena menunjukkan jumlah kambium. Ukuran diameter batang bawah juga menunjukkan umur dari batang bawah, besaran diameter batang bawah berbanding lurus dengan umur tua batang bawah. Hal ini sesuai dengan pendapat Li et al., (2019) yang menyatakan bahwa batang bawah yang terlalu tua maupun muda akan menjadi faktor keberhasilan sambungan.

Berdasarkan Tabel 1. dapat diketahui bahwa konsentrasi BAP memberikan hasil dengan pengaruh nyata terhadap waktu muncul tunas. Pemberian BAP dengan konsentrasi 200 ppm memberikan hasil paling signifikan dengan rata-rata waktu muncul tunas 14,93 hari dibandingkan dengan pemberian BAP dengan konsentrasi 0 ppm dan 100 ppm dengan rata-rata waktu muncul tunas 24,60 hari dan 19,60 hari (Tabel 1). Pemberian konsentrasi BAP 200 ppm menghasilkan waktu muncul tunas paling cepat dibandingkan dengan pemberian konsentrasi 0 ppm dan 100 ppm. Hal itu dikarenakan penambahan hormon sitokinin (BAP) dapat meningkatkan pembelahan sel sehingga proses pertautan dan kemunculan tunas pada entres terjadi lebih cepat. Menurut Schaller et al., (2015) pembelahan, pertumbuhan dan perkembangan sel tanaman dapat ditingkatkan dengan pemberian hormon sitokinin. Pembelahan sel akan memacu pertumbuhan kalus dan pembentukan kalus yang menentukan proses pertautan sambungan menjadi lebih cepat atau lebih lambat. Menurut Pratomo et al., (2010) tunas baru, cabang dan daun tanaman karet dapat dirangsang dengan pemberian BAP 250 ppm hingga 8 tunas baru. Pemberian perlakuan hormon sitokinin BAP sebesar 100 dan 200 ppm dapat mempercepat waktu munculnya tunas pada sambung pucuk sawo. Menurut Kamran et al., (2021) bahwa Waktu muncul tunas dapat ditingkatkan dengan pemberian sitokinin karena berpengaruh dalam pembelahan sel dan inisiasi pucuk

\section{Jumlah Tunas}

Hasil analisis ragam menunjukkan bahwa tidak terdapat interaksi antara diameter batang bawah dan konsentrasi BAP terhadap jumlah tunas tanaman sawo. Perlakuan diameter batang bawah berpengaruh terhadap jumlah tunas tanaman sawo, berdasarkan hasil uji lanjut DMRT $(P<0,05)$ disajikan pada Tabel 2 . Perlakuan konsentrasi BAP tidak berpengaruh terhadap jumlah tunas.

Berdasarkan Tabel 2. dapat diketahui bahwa ukuran diameter batang bawah ukuran kecil menghasilkan 
tunas paling banyak (2,20 tunas), sedangkan yang paling sedikit pada batang bawah ukuran besar $(1,87$ tunas) (Tabel 2). Hasil penelitian ini sejalan dengan penelitian Sudjijo, (2009) menyatakan bahwa ukuran diameter batang bawah tidak mempengaruhi jumlah tunas pada sambung pucuk. Selain itu, diduga yang mempengaruhi adalah kondisi mata tunas serta jumlah mata tunas yang ada pada entres yang disambungkan.

Tabel 2. Jumlah Tunas

\begin{tabular}{|c|c|c|c|c|}
\hline \multirow{2}{*}{$\begin{array}{c}\text { Diameter } \\
\text { Batang } \\
\text { Bawah }\end{array}$} & \multicolumn{3}{|c|}{ Konsentrasi BAP (ppm) } & \multirow{2}{*}{$\begin{array}{c}\text { Rata- } \\
\text { rata }\end{array}$} \\
\hline & 0 & 100 & 200 & \\
\hline Kecil & 1,00 & 1,60 & 4,00 & 2,20 \\
\hline Sedang & 0,40 & 1,20 & 2,60 & 1,40 \\
\hline Besar & 1,40 & 1,60 & 2,60 & 1,87 \\
\hline Rata-rata & $0,93 b$ & $1,47 b$ & $3,07 a$ & \\
\hline
\end{tabular}

Keterangan: Superskrip yang berbeda pada kolom atau baris rata-rata yang sama menunjukkan perbedaan nyata $(P<0,05)$. Superskrip yang berbeda pada matriks interaksi menunjukkan perbedaan nyata $(P<0,05)$.

Berdasarkan Tabel 2. dapat diketahui bahwa konsentrasi BAP berpengaruh nyata terhadap jumlah tunas. Rata-rata jumlah tunas dengan pemberian konsentrasi BAP 0 ppm, 100 ppm dan 200 ppm masingmasing adalah 0,93 tunas, 1,47 tunas dan 3,07 tunas (Tabel 2). Pada penelitian ini pemberian hormon sitokinin BAP dengan konsentrasi 200 ppm memberikan pengaruh terhadap jumlah tunas dibandingkan dengan pemberian konsentrasi 0 ppm dan 100 ppm. Konsentrasi BAP yang semakin tinggi berbanding lurus dengan jumlah tunas yang dihasilkan. Menurut Ermavitalini et al., (2021) bahwa konsentrasi BAP 100-200 ppm mempengaruhi peningkatan jumlah tunas baru rata-rata 5 tunas pada tanaman Mattiola incana. Hormon sitokinin (BAP) merupakan senyawa yang memiliki kemampuan sitokinensis atau pembelahan sel dalam jaingan dengan cara meningkatkan laju sintesis protein. Sitokinin sering digunakan dirasa paling efektif untuk merangsang pembentukan tunas, mengatur pertumbuhan daun dan pucuk dan menghambat proses penuaan. Menurut Pratomo et al., (2010) tunas baru, cabang dan daun tanaman karet dapat dirangsang dengan pemberian BAP 250 ppm hingga 8 tunas baru. Menurut Rochmatino \& Prayoga, (2011) jumlah tunas, jumlah dan dan tingkat keberhasilan hidup tanaman Adenium meningkat hingga $50 \%$ dengan pemberian hormon BAP 100ppm.

\section{Panjang Tunas}

Hasil analisis ragam menunjukkan bahwa terdapat interaksi antara diameter batang bawah dan konsentrasi BAP terhadap panjnag tunas tanaman sawo. Perlakuan diameter batang bawah berpengaruh terhadap panjang tunas tanaman sawo, berdasarkan hasil uji lanjut DMRT $(P<0,05)$ disajikan pada Tabel 3. Perlakuan konsentrasi BAP berpengaruh terhadap panjang tunas, berdasarkan hasil uji lanjut DMRT $(\mathrm{P}<0,05)$ disajikan pada Tabel 3.

Berdasarkan Tabel 3. menunjukkan bahwa terjadi peningkatan hasil panjang tunas seiring dengan penambahan konsentrasi BAP pada perlakuan ukuran diameter batang bawah kecil dan sedang. Pada ukuran diameter batang bawah sedang (A2) menghasilkan panjang tunas yang meningkat secara signifikan seiring bertambahnya pemberian konsentrasi BAP 0 ppm (S1), 100 ppm (S2) dan 200 ppm (S3). Pemberian zat pengatur tumbuh atau hormon akan meningkatkan panjang tunas pada teknik sambung pucuk. Menurut Lu et al., (2021) panjang tunas baru dapat meningkat karena dipengaruhi oleh pemberian hormon auksin dan sitokinin pada entres tanaman kakao menggunakan teknik sambung pucuk. Hasil panjang tunas paling baik dan berbeda nyata ditunjukkan oleh perlakuan diameter batang bawah sedang (A2) dengan pemberian konsentrasi BAP sebesar 200 ppm (S3). Hal ini diduga karena diameter batang bawah sedang memiliki jumlah meristem yang cukup banyak sehingga laju pertumbuhan tunas akan meningkat serta pemberian hormon BAP akan memberikan pengaruh nyata terhadap panjang tunas karena BAP merupakan hormon sitokinin yang dapat merangsang pembelahan, pertumbuhan dan perkembangan sel pada tanaman. Hal ini sesuai dengan pendapat Mertade \& Basri, (2011) bahwa ukuran diameter entres menentukan laju pertumbuhan panjang dan diameter tunas karena diduga entres dengan diameter lebih besar memiliki jumlah sel meristem lebih banyak dan pendapat Pratomo et al., (2010) bahwa tunas baru, cabang dan daun tanaman karet dapat dirangsang dengan pemberian BAP 250 ppm hingga 8 tunas baru.

Tabel 3. Panjang Tunas

\begin{tabular}{|c|c|c|c|c|}
\hline \multirow{2}{*}{$\begin{array}{c}\text { Diameter } \\
\text { Batang } \\
\text { Bawah }\end{array}$} & \multicolumn{3}{|c|}{ Konsentrasi BAP (ppm) } & \multirow{2}{*}{$\begin{array}{l}\text { Rata- } \\
\text { rata }\end{array}$} \\
\hline & 0 & 100 & 200 & \\
\hline Kecil & $0,54 \mathrm{~cd}$ & $0,84 \mathrm{bcd}$ & $1,14 \mathrm{bc}$ & $0,84 b$ \\
\hline Sedang & $0,70 \mathrm{~cd}$ & $1,52 a b$ & $2,30 a$ & $1,51 \mathrm{a}$ \\
\hline Besar & $0,42 \mathrm{~cd}$ & $0,24 d$ & $0,30 d$ & $0,32 c$ \\
\hline Rata-rata & $0,55 b$ & $0,87 a b$ & $1,20 a$ & \\
\hline
\end{tabular}

Keterangan: Superskrip yang berbeda pada kolom atau baris rata-rata yang sama menunjukkan perbedaan nyata $(P<0,05)$. Superskrip yang berbeda pada matriks interaksi menunjukkan perbedaan nyata $(\mathrm{P}<0,05)$.

Ukuran diameter batang bawah kecil (A1) menghasilkan panjang tunas yang meningkat namun tidak berbeda nyata pada pemberian konsentrasi BAP 100 ppm (S2) dan 200 ppm (S3) namun tidak secara signifikan (ilustrasi 1). Peningkatan panjang tunas tidak terjadi secara signifikan diduga karena penggunaan ukuran diameter batang bawah kecil (A1) pada sambung pucuk sawo. Ukuran diameter batang bawah yang kecil memiliki jumlah meristem yang masih terbatas dan umur batang bawah yang masih cukup muda (3-4 bulan) sehingga laju pertumbuhan panjang tunas tidak terjadi secara signifikan walaupun sudah dibantu dengan pemberian hormon sitokinin (BAP). Selain itu, tidak terjadi peningkatan panjang tunas secara signifikan disebabkan oleh ketersediaan cadangan makanan pada batang bawah sebagai sumber energi pembentukan dan pertumbuhan tunas yang terbatas karena ukuran diameter batang bawah kecil. Hal ini sesuai dengan pendapat Panjaitan et al., (2014) yang menyatakan bahwa adanya pengaruh nyata ukuran diameter terhadap panjang tunas dan diameter tunas disebabkan oleh jumlah cadangan makanan pada batang bawah sebagai sumber energi untuk pembentukan tunas sehingga tunas dapat tumbuh dengan optimum.

Ukuran diameter batang bawah besar (A3) dengan pemberian konsentrasi BAP 0 ppm (S1), 100 ppm (S2) dan 200 ppm (S3) tidak terjadi peningkatan panjang tunas (Tabel 3). Hal ini diduga karena penggunaan diameter batang bawah besar pada sambung pucuk 
sawo. Ukuran diameter batang bawah menunjukkan umur batang bawah, semakin besar ukuran diameter batang bawah maka semakin tua umur batang bawah tersebut. Penggunaan ukuran diameter batang bawah besar (A3) menghambat keberhasilan sambungan dan pertumbuhan tunas karena batang bawah dengan umur tua memiliki kekerasan kambium yang tinggi sehingga proses pertautan dan proses pengantaran hara ke entres akan terhambat walaupun diberi penambahan hormon BAP. Hal ini sesuai dengan penelitian Li et al., (2019) bahwa batang bawah yang terlalu tua maupun muda akan menjadi faktor keberhasilan sambungan dan penelitian Izadi et al., (2014) bahwa keberhasilan sambungan dan jumlah daun yang dihasilkan dipengaruhi oleh pemilihan batang bawah, seperti kondisi kesehatan batang bawah dan umur batang bawah.

\section{Jumlah Daun}

Hasil analisis ragam menunjukkan bahwa tidak terdapat interaksi antara diameter batang bawah dan konsentrasi BAP terhadap jumlah daun tanaman sawo. Perlakuan diameter batang bawah berpengaruh terhadap jumlah daun tanaman sawo, berdasarkan hasil uji lanjut DMRT $(P<0,05)$ disajikan pada Tabel 4. Perlakuan konsentrasi BAP tidak berpengaruh terhadap panjang tunas.

Tabel 4. Jumlah Daun

\begin{tabular}{ccccc}
\hline Diameter & \multicolumn{3}{c}{ Konsentrasi BAP $(\mathrm{ppm})$} & \\
\cline { 2 - 4 } $\begin{array}{c}\text { Batang } \\
\text { Bawah }\end{array}$ & 0 & 100 & 200 & Rata-rata \\
\hline Kecil & 6,00 & 7,20 & 8,40 & \\
Sedang & 3,00 & 4,40 & 5,60 & $4,30^{\mathrm{a}}$ \\
Besar & 1,00 & 3,20 & 3,40 & $2,53^{\mathrm{b}}$ \\
\hline Rata-rata & 3,33 & 4,93 & 5,80 & \\
\hline
\end{tabular}

Keterangan: Superskrip yang berbeda pada kolom atau baris rata-rata yang sama menunjukkan perbedaan nyata $(P<0,05)$. Superskrip yang berbeda pada matriks interaksi menunjukkan perbedaan nyata $(P<0,05)$.

Ukuran batang bawah diameter kecil $(0,55 \mathrm{~cm}-$ $0,65 \mathrm{~cm}$ ) memiliki hasil yang paling optimum pada parameter jumlah daun yaitu sebesar 7,20 daun sedangkan jumlah daun paling kecil pada ukuran diameter batang bawah besar yaitu 2,53 daun (Tabel 4). Ukuran diameter batang bawah kecil dan ukuran sedang berpengaruh terhadap jumlah daun yang dihasilkan. Hal ini terjadi karena pada batang bawah dengan ukuran tersebut terdapat jaringan xylem yang cukup banyak serta proses pembelahan sel masih terjadi secara tinggi sehingga transformasi hara dan air dapat berjalan dengan optimal. Pembelahan sel menjadi daun baru akan terjadi secara optimal apabila tanaman mendapat suplai hara yang cukup. Menurut Sudjijo, (2009) hara yang diserap oleh akar tanaman dapat didistribusikan dengan baik ke seluruh tanaman apabila proses pertautan sambungan berhasil.

Berdasarkan Tabel 4, dapat ditunjukkan bahwa konsentrasi BAP tidak berpengaruh nyata terhadap parameter jumlah daun. Konsentrasi BAP 200 ppm menghasilkan jumlah daun tertinggi (5,80 daun) sedangkan konsentrasi BAP 0 ppm menghasilkan jumlah daun terendah (3,33 daun). Menurut Pratomo et al., (2010) tunas baru, cabang dan daun tanaman karet dapat dirangsang dengan pemberian BAP 250 ppm hingga 8 tunas baru. Pemberian hormon BAP meningkatkan jumlah daun namun tidak memberikan pengaruh nyata, hal ini diduga kurangnya konsentrasi BAP yang diberikan dalam penelitian sambung pucuk sawo sehingga belum mendapatkan konsentrasi BAP yang tepat untuk hasil jumlah daun yang optimal. Menurut Hu et al., (2021) tunas baru, cabang dan daun tanaman karet dapat dirangsang dengan pemberian BAP 250 ppm hingga 8 tunas baru.

\section{Persentase Keberhasilan}

Semakin besar ukuran diameter batang bawah maka semakin kecil persentase hidup pada sambung pucuk sawo. Hal ini disebabkan karena ukuran diameter batang bawah berbanding lurus dengan umur batang bawah, penggunaan batang bawah dengan umur yang semakin tua maka akan menurunkan tingkat keberhasilan sambung pucuk. Menurut Izadi et al., (2014) keberhasilan sambungan dan jumlah daun yang dihasilkan dipengaruhi oleh pemilihan batang bawah, seperti kondisi kesehatan batang bawah dan umur batang bawah. Hal ini juga diperkuat oleh pendapat Handayani et al., (2013) bahwa penggunaan batang bawah dengan umur berbeda akan mempengaruhi hasil sambung pucuk pada tanaman manggis. Pemilihan batang bawah sangat penting karena mempengaruhi keberhasilan sambung pucuk, semakin tua umur batang bawah maka tingkat kekerasan kambium juga meningkat sehingga proses pertautan sambungan akan menurun.

Tabel 5. Persentase Keberhasilan

\begin{tabular}{ccccc}
\hline Diameter & \multicolumn{3}{c}{ Konsentrasi BAP $(\mathrm{ppm})$} & \\
\cline { 2 - 4 } Batang & 0 & 100 & 200 & Rata-rata \\
Bawah & & & & \\
\hline Kecil & 60,00 & 80,00 & 80,00 & 73,33 \\
Sedang & 70,00 & 60,00 & 70,00 & 63,33 \\
Besar & 50,00 & 30,00 & 30,00 & 36,67 \\
\hline Rata-rata & 60,00 & 56,67 & 60,00 & \\
\hline
\end{tabular}

Hasil analisis pada Tabel 5 menunjukkan bahwa hasil optimal pada parameter persentase keberhasilan terdapat pada perlakuan diameter batang bawah kecil dengan pemberian konsentrasi BAP 100 ppm dan 200 ppm (A1S2 dan A1S3) sebesar 80\%. Pemberian hormon sitokinin (BAP) akan merangsang pembelahan sel tanaman sehingga meningkatkan persentase keberhasilan pertautan sambungan dan mempercepat waktu muncul tunas. Menurut Halawa et al., (2021) waktu muncul tunas akan dipercepat dengan penambahan sitokinin. Waktu muncul tunas dapat ditingkatkan dengan pemberian sitokinin karena berpengaruh dalam pembelahan sel dan inisiasi pucuk. Pemberian hormon BAP akan memacu pembelahan dan penambahan ukuran pada pertumbuhan tunas. Menurut Pratomo et al., (2010) bahwa tunas baru, cabang dan daun tanaman karet dapat dirangsang dengan pemberian BAP 250 ppm hingga 8 tunas baru. Pada penelitian ini menunjukkan bahwa batang bawah dengan diameter kecil yang memiliki umur 3-4 bulan dengan pemberian zat pengatur tumbuh memberikan respon positif atau hasil optimal terhadap persentase keberhasilan sedangkan batang bawah dengan diameter lebih besar yang memiliki umur lebih tua walaupun diberikan zat pengatur tumbuh dengan konsentrasi yang sama tidak menunjukkan hasil yang lebih baik. 


\section{KESIMPULAN}

Praktik sambung pucuk tanaman sawo dengan keberhasilan tinggi adalah dengan penggunaan batang bawah ukuran sedang dan kecil dengan penggunaan BAP konsentrasi 200 ppm.

\section{DAFTAR PUSTAKA}

Ahanger, M. A., Mir, R. A., Alyemeni, M. N., \& Ahmad, P. (2020). Combined effects of brassinosteroid and kinetin mitigates salinity stress in tomato through the modulation of antioxidant and osmolyte metabolism. Plant Physiology and Biochemistry, 147(September 2019), $31-42$. https://doi.org/10.1016/j.plaphy.2019.12.007

Barbalho, S. M., Bueno, P. C. D. S., Delazari, D. S., Guiguer, E. L., Coqueiro, D. P., Araújo, A. C., De Souza, M. D. S. S., Farinazzi-Machado, F. M. V., Mendes, C. G., \& Groppo, M. (2015). Antidiabetic and antilipidemic effects of manilkara zapota. Journal of Medicinal Food, 18(3), 385-391. https://doi.org/10.1089/jmf.2013.0170

BPS. (2018). Statistik tanaman buah-buahan dan sayuran tahunan Indonesia tahun 2017. Badan Pusat Statistik.

BPS. (2019). Statistik tanaman buah-buahan dan sayuran tahunan Indonesia 2019. Badan Pusat Statistik.

Bucci, R., Vaghi, F., Erba, E., Romanelli, A., Gelmi, M. L., \& Clerici, F. (2020). Peptide grafting strategies before and after electrospinning of nanofibers. Acta Biomaterialia, 122, 82-100. https://doi.org/10.1016/j.actbio.2020.11.051

Ermavitalini, D., Rahayu, A. E., Kurniawan, H. B., \& Prasetyo, E. N. (2021). Effect of Indole 3-Acetic Acid (IAA) and 6-Benzyl Amino Purine (BAP) on Nannochloropsis sp. culture growth. IOP Conference Series: Earth and Environmental Science, 649(1). https://doi.org/10.1088/1755-1315/649/1/012003

H Panjaitan, L. R., Ginting, J., \& Haryati, H. (2014). Respons pertumbuhan berbagai ukuran diameter batang stek bugenvil (Bougainvillea Spectabiliswilld.) terhadap pemberian zat pengatur tumbuh. Jurnal Agroekoteknologi Universitas Sumatera Utara, 2(4), 101393. https://doi.org/10.32734/jaet.v2i4.8429

Halawa, M., Cortleven, A., Schmülling, T., \& Heyl, A. (2021). Characterization of CHARK, an unusual cytokinin receptor of rice. Scientific Reports, 11(1), 110. https://doi.org/10.1038/s41598-020-80223-2

Handayani, R. S., Poerwanto, R., Purwito, A., \& Ermayanti, M. (2013). Pengaruh batang bawah dan jenis tunas pada mikrografting manggis (Garcinia mangostana) secara in vitro. J. Agron. Indonesia, 41(1), 47-53.

Hu, Y., Omary, M., Hu, Y., Doron, O., Hoermayer, L., Chen, Q., Megides, O., Chekli, O., Ding, Z., Friml, J., Zhao, Y., Tsarfaty, I., \& Shani, E. (2021). Cell kinetics of auxin transport and activity in Arabidopsis root growth and skewing. Nature Communications, 12(1), 1-13. https://doi.org/10.1038/s41467-021-21802-3

Izadi, Z., Zarei, H., \& Alizadeh, M. (2014). Effect of time, cultivar and rootstock on success of rose propagation through stenting technique. American Journal of Plant
Sciences,

05(11),

https://doi.org/10.4236/ajps.2014.511178

Kamran, M., Danish, M., Saleem, M. H., Malik, Z., Parveen, A., Abbasi, G. H., Jamil, M., Ali, S., Afzal, S., Riaz, M., Rizwan, M., Ali, M., \& Zhou, Y. (2021). Application of abscisic acid and 6-benzylaminopurine modulated morpho-physiological and antioxidative defense responses of tomato (Solanum lycopersicum L.) by minimizing cobalt uptake. Chemosphere, 263, 128169.

https://doi.org/10.1016/j.chemosphere.2020.128169

Li, Y., Sun, W., Liu, F., Cheng, J., Zhang, X., Zhang, H., \& Zhao, Y. (2019). Methods for grafting Arabidopsis thaliana and Eutrema salsugineum. Plant Methods, 15(1), 1-9. https://doi.org/10.1186/s13007-019-0477$\mathrm{x}$

Lu, Z., Peng, B., Ebert, B. E., Dumsday, G., \& Vickers, C. E. (2021). Auxin-mediated protein depletion for metabolic engineering in terpene-producing yeast. Nature Communications, 1051(12), 1-13. https://doi.org/10.1038/s41467-021-21313-1

Maiti, \& Bidinger. (2018). Pengaruh aplikasi ZPT sitokinin terhadap kompatibilitas entres pada teknik sambung pucuk tanaman asam gelugur (Garcinia atroviridis Griff ex T. Anders). Journal Agroteknologi FP USU, 6(4), 801-808.

Mertade, N., \& Basri, Z. (2011). Pengaruh diameter pangkal tangkai daun pada entres terhadap pertumbuhan tunas kako. Media Litbang Sulteng, $4(1), 1-7$.

MIR, M., \& Kumar, A. (2011). Effect of different methods, time and environmental conditions on grafting in walnut. International Journal of Farm Sciences, 1(2), 17-22.

Pratomo, B., Hanum, C., \& Putri, L. (2010). Pertumbuhan okulasi tanaman karet (Hevea brassiliensis Muell arg.) dengan tinggi penyerongan batang bawah dan Benzilaminopurin (BAP) Pada Pembibitan Polibeg. Jurnal Pertanian Tropik, 8719(2006), 119-123.

Rochmatino, \& Prayoga, L. (2011). Pengaruh pemberian NAA dan Sitokinin (BAP) terhadap pertumbuhan hasil teknik sambung Adenium sp. AGRITECH, 8(2), 96104.

Russo, L., Buckley, Y. M., Hamilton, H., Kavanagh, M., \& Stout, J. C. (2020). Low concentrations of fertilizer and herbicide alter plant growth and interactions with flower-visiting insects. Agriculture, Ecosystems and Environment, 304(January), 107141. https://doi.org/10.1016/j.agee.2020.107141

Sari, I., \& Susilo, A. (2012). Keberhasilan sambungan pada beberapa jenis batang atas dan famili batang bawah kakao (Theobroma cocoa L.). Pelita Perkebunan, 28(2), 72-81. https://doi.org/10.22302/iccri.jur.pelitaperkebunan.v2 $8 \mathrm{i} 2.200$

Schaller, G. E., Bishopp, A., \& Kieber, J. J. (2015). The yin-yang of hormones: Cytokinin and auxin interactions in plant development. Plant Cell, 27(1), 44-63. https://doi.org/10.1105/tpc.114.133595

Setyowati, D. L. (2008). Iklim mikro dan kebutuhan ruang terbuka hijau di kota Semarang. Jurnal Manusia Dan 


\section{Lingkungan, $\quad$ 15(3),} https://doi.org/10.22146/jml.18685

Sudjijo. (2009). Pengaruh ukuran batang bawah dan batang atas terhadap pertumbuhan durian monthong, Hepe, Dan DCK-01. Jurnal Hortikultura, 19(1), 89-94. https://doi.org/10.21082/jhort.v19n1.2009.p

Sudrajat, D.J., M. (2010). Variation of seed morphology and germination pre treatment response from five populations of sawo kecik (Manilkara kauki (L.) Dubard). Jurnal Penelitian Hutan Tanaman, 7(2), 6776.

Sukendro, A., Mansur, I., \& Trisnawati, R. (2010). Studi pembiakan vegetatif Intsia bijuga (Colebr.) O.K. Melalui Grafting. Silvikultur Tropika, 01, 6-10.
Widiatmoko, E., \& Ashari, S. (2018). Hubungan antara batang bawah dengan batang atas pada metode topworking tanaman durian (Durio zibethinus Murr) di Kecamatan Ngantang. Jurnal Produksi Tanaman, $6(1), 32-37$.

Woo, P. F., Yim, H. S., Khoo, H. E., Sia, C. M., \& Ang, Y. K. (2013). Effects of extraction conditions on antioxidant properties of sapodilla fruit (Manilkara zapota). International Food Research Journal, 20(5), 2065-2072.

Yanti, I. T., Suladjari, \& Yuniastuti, E. (2013). Pengaruh pemberian air kelapa dan tipe sambungan terhadap keberhasilan sambung pucuk durian ( Durio zibethinus $\mathrm{M}$.). Agrosains: Jurnal Penelitian Agronomi, 15(2), 46-49. 